\title{
A Dynamic Analysis of Licensing: The "Boomerang" Effect and Grant-Back Clauses
}

\author{
by
}

Jay Pil Choi, Columbia University

July 1995, Revised April 1997

Discussion Paper Series No. 9697-16

$$
\begin{aligned}
& \text { dp } 969-6 \\
& r 603: 35
\end{aligned}
$$




\title{
A Dynamic Analysis of Licensing: The "Boomerang" Effect and Grant-Back Clauses
}

\author{
by \\ Jay Pil Choi* \\ July 1995 \\ revised, April 1997
}

\begin{abstract}
This paper develops an incomplete contract model of the licensing relationship to analyze the dynamic effects of licensing on R\&D competition in the innovation market and to examine the rationale for often observed grant-back clauses. Of particular concern are how the consideration of future competition distorts the licensing relationship and how the "grant-back" clause can mitigate this distortion. I also evaluate the validity of the casual antitrust argument that grantback clauses may adversely affect competition because they reduce the licensee's incentive to engage in R\&D and thereby limit rivalry in innovation markets.
\end{abstract}

Correspondent:

Jay Pil Choi

Department of Economics

Columbia University

New York, NY 10027

U.S.A.

Tel.: 212-854-5488

Fax.: 212-854-8059

E-mail: jpc8@columbia.edu

*I am grateful to Prajit Dutta, Oliver Hart, Eric Maskin, Michael Whinston, and SangSeung Yi for their comments. The preliminary draft of this paper was written while I was visiting the Center for Economic Studies, University of Munich. Financial support from the Social Science Research Council through the Abe Fellowship Program is gratefully acknowledged. 


\section{Introduction}

Licensing is a voluntary form of dissemination whereby an inventor can enjoy at least some of the gains to trade by availing other parties of the use of his superior knowledge (see Kamien [1992] for an excellent survey on licensing). Firms often grant licenses because they do not have the resources to achieve full commercial exploitation of their intellectual property by themselves. The inventor, for instance, may lack complementary assets to fully appropriate the potential of the technology (Teece, 1986) and/or may have insufficient financial resources to serve all geographic markets. In this case, licensing, by leveraging on other firms' resources, can serve as a device to broaden geographic and product markets.

Granting a license, however, also poses substantial risks for the inventor such as the risk of piracy, the loss of control over exploitation of the technology, and the dependence on others for revenue (Dratler, 1994). Moreover, licensing creates competition by giving away proprietary know-how to potential rival firms. One of the major risks involved with creating a competitor is that the licensing firm may lose its technological "edge" by setting up its future competitor in innovation markets. In particular, granting others the right to use its intellectual property may enable them to develop new products, which make the licensed technology obsolete and leave the licensor in backwater of technology. ${ }^{1}$

In this context, it is not surprising to witness empirical evidence that firms are often reluctant to license their cutting-edge technologies since they may be giving their rivals the knowledge necessary to develop a better technology [Roberts and Mizouchi (1988) and Davies (1977)]. ${ }^{2}$ As a response to this problem, it has also been suggested

\footnotetext{
${ }^{1}$ For instance, it has often been suggested that myopic U.S. firms sold their future by licensing the stateof-the-art technologies for short-term profits. As a result, they lost ground to their competitors in the succeeding generation of technological development. The VCR and the semiconductor are two prominent examples.

2 According to Roberts and Mizouchi (1988), "[F]irms need to be aware with regards to licensing that the technology obtainable through these arrangements might not be state of the art." They quote one senior manager of Genetics Institute saying that the technology they license to outsiders is not the most advanced
} 
that a "technology flowback" provision in the contract that requires the licensee to share any advances or improvements in the licensed technology with the licensor, might remedy the licensor's problem of losing competitive advantage to the licensee in product development (see Shapiro (1985) and Rothstein and Willgohs [1988]). In fact, Caves et al. (1983) report that 43 percent of licensing agreements contain such grant-back clauses. Despite these concerns, the formal analysis of the effect of the licensing on future $R \& D$ competition has been relatively sparse. Most of the licensing literature, in contrast, is concerned with the impact of licensing on the competition in the current product market [Katz and Shapiro (1985) and Kamien (1992)]. In this paper, I analyze the dynamic effects of licensing on the competitiveness of the licensor in the innovation market and examine the rationale for often observed grant-back clauses. Of particular concern are how the consideration of future competition distorts the licensing relationship and how the "grant-back" clause can mitigate this distortion. In the process, I also evaluate the validity of the casual antitrust argument that grantback clauses may adversely affect competition because they reduce the licensee's incentive to engage in R\&D and thereby limit rivalry in innovation markets.

The basic premise of the paper is that the market for information is replete with imperfection and this is reflected in the incompleteness of licensing agreements. In particular, the nature of knowledge to be transferred is not well-defined in that it cannot be specified exactly in the contract; the technology concerned contains a highly tacit component which is informal and less codified than usually assumed in the licensing literature. ${ }^{3}$ Which type of technology is transferred may be observable to the parties in the relationship but not verifiable to a third party. Henceforth, it may not be enforceable in court. I assume that the contract can specify the lump-sum payment and/or royalty fee which depends on the verifiable quantity produced by using the technology licensed, and

one. Davies (1977) also documents that British "companies with radically new products were concerned not to disclose them in the Indian market, preferring to license earlier generations of expertise." ${ }^{3}$ Berrill (1964) points out that "only the broad outlines of technical knowledge are codified by nonpersonal means of intellectual communication". 
may specify the allocation of property rights on any forthcoming improvement based on the licensed technology. In this case, there may be conflicts in the type of technology that is actually delivered and the one that is desired to be delivered unless the contract is designed to be incentive-compatible. This implies that the process of technology transfer is susceptible to the moral hazard problem. The terms of technology licenses should reflect this imperfection of the license market [Caves et al. (1983)]. The incomplete contract approach in this paper, thus provides one explanation why, in practice, licensing contracts are predominantly royalty-based ${ }^{4}$; quantity-dependent royalty payments provide the only connection between successful transfer and the returns accruing to the licensor [Davies (1977)].

Incorporating the element of moral hazard in the technology transfer process will be shown to shed some light on issues that cannot be handled in more conventional models of licensing. For instance, I argue that the possibility of leapfrogging by the potential licensee in and of itself cannot be the reason for withholding the frontier technologies. The reason is that if this possibility is foreseen by the parties concerned, the licensor can be potentially compensated for any future loss of competitiveness due to the technology transfer. Therefore, the current theory, if there is one, is deficient for it fails to reveal the logical steps that carry it from the possibility of leapfrogging by the licensee to the reluctance of the licensor to transfer the cutting-edge technologies.

To make my point, I first demonstrate that if a complete contract can be written, the best available technology will always be licensed only with a lump-sum payment, simply because it enables the licensee to produce more efficiently; the first-best outcome is achieved and grant-back clauses are not necessary. This leads me to conclude that the real reason for the failure of licensing originates from the inability of the parties to the

\footnotetext{
${ }^{4}$ According to Rostoker (1984), licensing with fixed fee alone was used only 13 percent of the time. In contrast, royalty plus fixed fee licensing was used 46 percent of time and royalty alone was used 39 percent of time. In a study on international technology licensing, Contractor (1981) also concludes that "no all-encompassing generalization can be made beyond the apparent ubiquity of royalties as a mode of payment."
} 
licensing relationship to write a complete contract. Without a commitment mechanism for the licensor, the contract should be incentive compatible for the best technology to be transferred in order to prevent ex post opportunism. It will be shown that a quantitydependent royalty payment can serve as a hostage to facilitate the transfer of the best technology. The inclusion of the royalty rate introduces an artifical cost for the licensee and entails allocative inefficiency. If this cost of the incentive compatibility constraint (ICC) is too high, the best technology will not be transferred. Thus, the incomplete contract approach in this paper will make explicit the mechanism by which the transfer of cutting-edge technology is hindered. Then, I demonstrate how the grant-back clause can relax the incentive compatibility constraint and facilitate the transfer of the best technology available.

As pointed out earlier, the effect of licensing on competition in the innovation market has not received sufficient attention in the formal analysis. The main reason for the scarcity of the dynamic analysis of licensing lies in the typical assumption in the literature that the firm's current technological capability has no bearing on its capability to innovate. Thus, every firm is equally capable to develop new products and competes on a level playing field in the innovation market. ${ }^{5}$ One consequence of this assumption is the Arrow's (1962) celebrated "replacement effect" which induces an incumbent to have less chance to innovate than potential entrants as the incumbent rests on his laurels. ${ }^{6}$ This assumption is also responsible for Gallini's (1984) "deterrence by market sharing" result in which the incumbent shares the current market by licensing to a rival firm in order to reduce the rival firm's incentive to innovate. ${ }^{7}$ In reality, however, the innovation process is cumulative and licensing of a new technology serves as a stepping stone for further

\footnotetext{
${ }^{5}$ For instance, Gallini and Winter (1985) assume that research outcomes yield random production costs whose distribution is independent of the current costs (italics added).

${ }^{6}$ See also Reinganum (1985) for an industry evolution model of patent race in which the replacement effect is responsible for the Schumpeterian process of creative destruction.

${ }^{7}$ This type of strategic licensing is called ex ante licensing in Gallini and Winter (1985) to contrast from the licensing for the purpose of enhancing the production technology after the realization of R\&D which is called ex post licensing.
} 
developments of the licensed technology [Scotchmer (1991) and Green and Scotchmer (1995)]. Unless the knowledge spillover from the technology holder is complete and costless, licensing will facilitate the development of new products and the licensor runs the risk of being preempted by the licensee in the innovation market. This paper, in contrast, incorporates the cumulative nature of innovation and provides a framework to analyze dynamic issues associated with licensing. ${ }^{8}$

It should be mentioned that a small number of papers analyze the impact of licensing on R\&D incentives. Grossman and Shapiro (1986) and Fershtman and Kamien (1992) analyze the condition under which the licensing of the intermediate result can be jointly attractive in a multi-stage $R \& D$ game and how the possibility of licensing influences the pace of innovation. However, these papers consider a case where the object of licensing is an intermediate result which is of no value in itself and thus, is devoid of any interaction between the current product market competition and the future R\&D competition.

In spirit, this paper is closely related to a recent paper by Aghion and Tirole (1994) who open the black box of "the management of innovation" from an organizational point of view. Using the incomplete contract framework pioneered by Grossman and Hart (1986), they demonstrate that explicitly incorporating the imperfections of the innovation market in the analysis can generate useful insights on the management of innovation. The analysis of technology transfer in this paper is another step in that direction. ${ }^{9}$

The remainder of the paper is organized in the following way. In section II, I set up a basic model to analyze the dynamic consequences of licensing and provide a rationale for the inclusion of the so-called grant-back clause. Section III concerns the effect of the

\footnotetext{
${ }^{8} \mathrm{Katz}$ and Shapiro (1987) analyzes the possibility of postdevelopment licensing on R\&D competition. In contrast, this paper is interested in the effect of predevelopment licensing on R\&D competition. ${ }^{9}$ In a companion paper (Choi, 1995), I also apply the incomplete contract framework to a situation in which effective transmission of knowledge requires costly inputs which cannot be contracted directly. It is shown that the introduction of inputs that are not contractible and costly explains the prevalence of royalty contracts in the licensing relationship. Moreover the model relates the size of the royalty rate to the parameters that represent the circumstances under which the concerned parties operate.
} 
grantback clause on the $R \& D$ incentives. In particular, I examine the validity of the concern that the inclusion of the grantback clause has anti-competitive effects in reducing the rivalry in the R\&D market. Section IV analyzes the optimal licensing contract in the presence of $R \& D$ competition. Section $V$ contains concluding remarks.

\section{The Basic Model: An Incomplete Contract Approach to Technology Transfer}

I consider a technology transfer between two firms which operate in two different markets. ${ }^{10}$ I assume that these two markets are segmented. Thus, there is no direct competition between the licensor and the licensee in the same market. For instance, these two firms may be located in two different countries and due to the required "localization" of the product either to comply with local regulations or to satisfy local customers and tastes, licensing may be a better option to serve a foreign market. Alternatively, these two firms may be in different industries serving different customer bases even though they are related in that one firm's basic technology can be used by the other firms as well. This assumption spares an analysis of the competitive effect of licensing on the product market. ${ }^{11}$ Licensing, however, may give the licensee the knowledge necessary to develop a better technology and may create competition in the innovation market. Both parties are assumed to be risk-neutral and have reservation utility of zero. There are many potential licensees. As a result, the licensor has the bargaining power and makes a take-it-or-leaveit offer to the licensee. The distribution of the bargaining power has no consequences for efficiency in my framework since I do not assume any cash constraint for either party. ${ }^{12}$

\footnotetext{
${ }^{10} \mathrm{I}$ assume that the technology is licensed to only one firm in a given market. This assumption is in accord with Firestone's (1971) finding that most licenses are sold to a single firm. This is also consistent with the empirical evidence of costly technology transfer, which can be regarded as a fixed cost of production. For instance, in Teece's (1977) study on 26 international technology projects, the transfer costs ranged from $2 \%$ to $59 \%$ of total project cost. See Choi (1995) for an analysis of costly technology transfer in the presence of double moral hazard.

${ }^{11}$ Licensing to other firms operating in the same market invites tough competition and lowers the industry's profit. Katz and Shapiro (1985) analyzes the conditions under which licensing increases the industry's profit and, therefore, licensing occurs between firms in the same market.

12 In contrast, in Aghion and Bolton (1992) and Aghion and Tirole (1994), ex ante bargaining power influences the size of the total profits as well as the distribution of them due to the cash constraint facing one of the parties to the contract.
} 
I first argue that the possibility of leapfrogging by the potential licensee in and of itself cannot be the reason for the licensor's reluctance to transfer the cutting-edge technologies. If the possibility of leapfrogging is foreseen by the parties concerned, the licensor can be potentially compensated for any future loss of competitiveness due to the technology transfer. To make my point, I demonstrate that if a complete contract can be written, the best available technology will always be licensed simply because the first-best outcome requires production efficiency [Coase, 1960]. Thus, the real reason for the failure of licensing originates from the inability of the parties to the licensing relationship to write a complete contract.

To formalize the idea, I assume that there are two types of technology that can be licensed: the core and the peripheral technologies. The core technology differs from the peripheral technology in two respects. First, the core technology is superior to the peripheral in that it enables the licensee to produce at a lower cost; the production cost with the core technology is $\underline{c}$ while the production cost with the peripheral technology is $\bar{c}$, where $\underline{c}<\bar{c}$. In addition, the transfer of core technology may enable the licensee to develop a future generation of related product and may create a competitor to the licensor in the future. ${ }^{13}$

To determine which type of technology will be transferred in the licensing relationship, it is necessary to describe the nature of future competition. To accommodate the possibility of future competition, consider a two period model (see Figure 1).

Once there is a transfer of the core technology, there will be a race to be the first one to develop a new generation of the product which will render the old product obsolete. The new product is assumed to be sold in the second period. The R\&D competition occurs in the intervening period between the end of the first period and the

\footnotetext{
${ }^{13}$ Rockett (1990) also allows the licensor to choose which versions of the technology to license when the licensor and the licensee are duopolists competing in the same market. In her paper, the quality of the licensed technology affects the licensee's ability to imitate. Different versions of the technology, however, are fully characterized by their corresponding marginal costs. Therefore, the effects of the quality of licensed technology and the grant-back clause on future product development are not considered.
} 
beginning of the second period. The value of winning the race is $\mathrm{V}$. The loser gets nothing. ${ }^{14}$ The first one to develop captures the whole value because further entry is blocked by the patent. Alternatively, the assumption of Bertrand competition and a small sunk cost of entry will ensure no further entry.

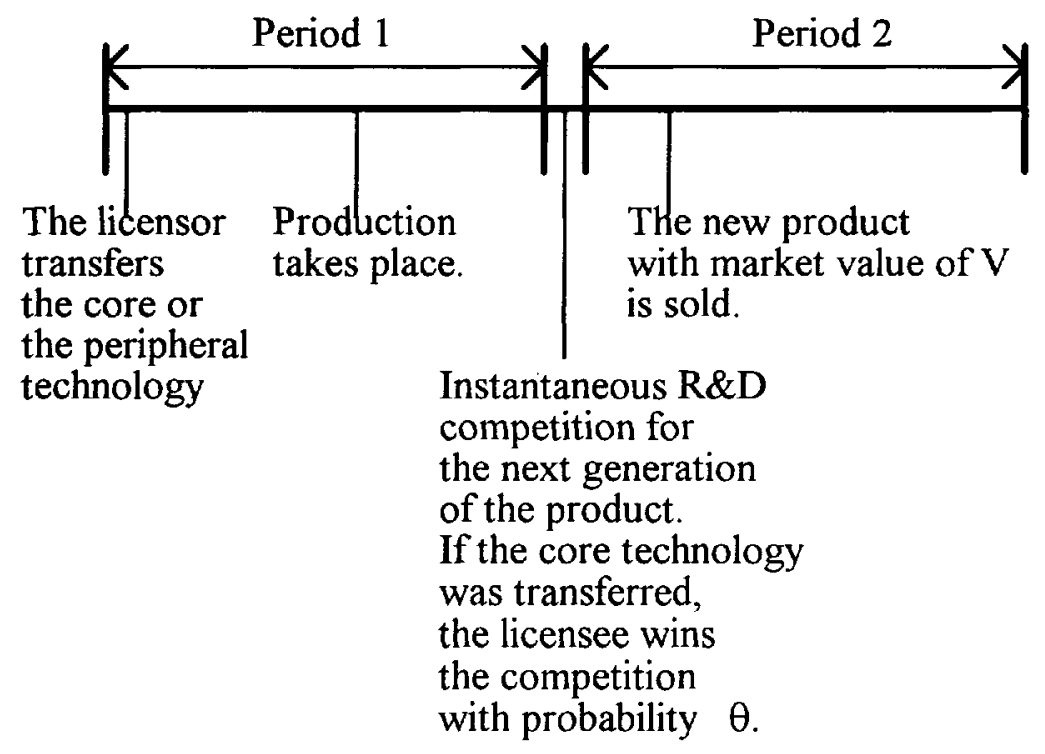

Figure 1. Timing of the Licensing and R\&D Competition.

I assume that the transfer of the core technology endows the licensee with the ability to win in the future competition with probability $\theta$. For instance, we can imagine a situation in which the licensee's hazard rate of innovation with the transfer of the core technology is given by $\lambda$, which parametrizes the ability of the licensee to absorb the technology (see Cohen and Levinthal [1989]). However, with the transfer of peripheral technology, the licensee cannot succeed in the development of the new technology regardless of its ability level. ${ }^{15}$ Let $v$ denote the hazard rate for the licensor. Then,

${ }^{14}$ The payoff structure of "the-winner-takes-all" is not necessary for my argument. All I need is that the winner's payoff is larger than that of the loser and the game exhibits the feature of a race. If the payoff structure is reversed and the game is one of waiting, there is no need to worry about the transfer of the core technology.

${ }^{15}$ More generally, I could have assumed that the hazard rates for the licensee are given by $f(\lambda)$ and $g(\lambda)$ when the core and the peripheral technologies are transferred, respectively, without altering any qualitative results. Then, the main argument that follows will be valid if we assume that $h(\lambda)=f(\lambda)-g(\lambda)$ is increasing in $\lambda$. 
$\theta=\lambda /(\lambda+v)$. Since there is a one-to-one correspondence between $\theta$ and $\lambda$, henceforth, I will parametrize the absorptive capacity with $\theta$ when the core technology is transferred. Let $\phi_{S}^{C O R E}$ and $\phi_{B}^{C O R E}$ denote the expected future (second period) payoffs for the licensor (seller) and the licensee (buyer) when the core technology is transferred. ${ }^{16}$ Then, abstracting away from discounting and $R \& D$ costs, we have ${ }^{17}$ :

$$
\phi_{S}^{C O R E}=(1-\theta) \mathrm{V}, \quad \phi_{B}^{C O R E}=\theta \mathrm{V}
$$

In contrast, with the transfer of the peripheral technology, the licensor captures the market with probability one since there is no danger of being preempted by the licensee.

Therefore, the future payoffs when the peripheral technology is transferred are:

$$
\phi_{S}^{P E R I}=\mathrm{V}, \quad \phi_{B}^{P E R I}=0
$$

Let $\pi(\mathrm{c})$ and $\mathrm{q}(\mathrm{c})$ be the (reduced) profit function for the licensee and the corresponding profit maximizing level of output in the first period, respectively, when the constant marginal cost is given by $\mathrm{c} .{ }^{18}$ Let me also denote $R^{C O R E}(\mathrm{r})$ and $R^{P E R I}(\mathrm{r})$ as the royalty income for the licensor when the royalty rate is $\mathrm{r}:{ }^{19}$

$$
R^{C O R E}(\mathrm{r})=\mathrm{rq}(\underline{c}+\mathrm{r}), R^{P E R}(\mathrm{r})=\mathrm{rq}(\bar{c}+\mathrm{r})
$$

Now suppose that a complete contract can be written specifying which type of technology will be transferred. If the core technology is transferred with the royalty rate of $\mathrm{r}$, the payoffs for the licensor, excluding fixed fee component, are $\phi_{S}^{C O R E}+R^{C O R E}(\mathrm{r})=$ $(1-\theta) V+r q(\underline{c}+r)$. In addition, the licensor can extract the licensee's payoffs from the

${ }^{16}$ Subscripts S and B denote the licensor (seller) and the licensee (buyer), respectively.

${ }^{17}$ Once again, this assumption is not crucial and is made only for expositional simplicity. We can easily construct a full-fledged $R \& D$ model that accounts for $R \& D$ cost and discounting without affecting any qualitative results that follow.

${ }^{18}$ That is, $q(c)=\operatorname{argmax}[P(q) q-c q]$ and satisfies the first-order condition $P^{\prime} q+P=c$, when $P($.$) is the$ inverse demand function. Note that by the envelope theorem, $\pi^{\prime}(c)=-q(c)$.

${ }^{19}$ It should be mentioned that the exclusive focus on the linear royalty payment scheme in this paper does not entail any loss of generality because any outcome induced by a nonlinear schemes can be replicated by a linear one. Consider the second-best contract with a general royalty payment of $\mathrm{R}(\mathfrak{q})$. (I considered only the case where $R(q)=r q$ in the paper.) Let $\widetilde{q}$ be the output induced by this scheme. Then, it can be easily verified, by comparing the first-order conditions, that the same outcome with $R(q)$ can be achieved using a linear scheme with the royalty rate of $r=R^{\prime}(\widetilde{q})$ accompanied by an appropriate adjustment of the fixed fee.This observation has also been made by Bhattacharyya and Lafontaine (1995) and Romano (1994). 
technology transfer in the form of a fixed fee, which is given by:

$$
F^{C O R E}=\pi(\underline{c}+r)+\theta \mathrm{V}
$$

Therefore, the licensor's payoffs with the transfer of the core technology are:

$$
\begin{aligned}
\Pi^{C O R E}(\theta) & =R^{C O R E}(\mathrm{r})+F^{C O R E}+\phi_{S}^{C O R E} \\
& =\mathrm{rq}(\underline{c}+\mathrm{r})+[\pi(\underline{c}+\mathrm{r})+\theta \mathrm{V}]+(1-\theta) \mathrm{V}=\mathrm{rq}(\underline{c}+\mathrm{r})+\pi(\underline{c}+\mathrm{r})+\mathrm{V}
\end{aligned}
$$

$\Pi^{\text {CORE }}$ will be maximized when royalty rate, $r$, is set at zero since by using the envelope theorem, we have $\mathrm{d}[\mathrm{r} \mathrm{q}(\underline{c}+\mathrm{r})+\pi(\underline{c}+\mathrm{r})] / \mathrm{dr}=\mathrm{q}^{\prime}(\underline{c}+\mathrm{r})<0$. Since any efficiency gain by the licensee can be extracted by a fixed fee, there is no reason to distort the licensee's effective $\mathrm{MC}$ by introducing a royalty rate. Therefore, the payoff for the licensor when the core technology is transferred is given by:

$$
\Pi^{C O R E}(\theta)=\pi(\underline{c})+\mathrm{V}
$$

Note that $\Pi^{\text {CORE }}(\theta)$ is independent of $\theta$. The reason is that any loss of competitive advantage by the licensor will be exactly offset by the corresponding increase in the fixed fee.

Similarly, I can derive the payoffs for the licensor when the peripheral technology is transferred. The payoff for the licensee which can be extracted as a fixed fee is:

$$
F^{P E R I}=\pi(\bar{c})+\phi_{B}^{P E R I}=\pi(\bar{c})
$$

In this case also, the royalty rate will be set at zero for the same reason. Therefore, the payoff from transferring the peripheral technology is given by:

$$
\begin{aligned}
\Pi^{P E R I}(\theta) & =R^{P E R I}(0)+F^{P E R I}+\phi_{S}^{P E R I} \\
& =\pi(\bar{c})+\mathrm{V}
\end{aligned}
$$

Since $\pi(\underline{c})>\pi(\bar{c})$, the licensor will always prefer to transfer the core technology. This vindicates my claim that the possibility of losing future competition alone cannot explain the nonoccurrence of technology transfer in the core technology as future competition from the licensee becomes more formidable. The intuition is quite simple. Since the licensor can extract all the surplus from the licensee via a fixed fee, the first-best outcome is achieved by maximizing the available pie in the relationship, which stipulates 
that the most efficient technology be transferred at the royalty rate of zero.

Proposition 1. With a complete contract, the core technology will always be transferred in return for a lump-sum payment, regardless of the consideration of future competition.

Proposition 1 is nothing but an extension of the Coase theorem in that royalties are distortionary and the transfer of inferior technology involves production inefficiency.

Proposition 1 thus suggests that the failure to transfer the core technology is a result of the inability of the concerned parties to write a complete contract. ${ }^{20}$

More specifically, assume that the license contract cannot specify which types of technology will be transferred. Even though which elements of the technology constitute the core component may be well-understood by the parties to the relationship, they may be difficult to convey to a third party. One way to interpret this situation is that the amount of public information disclosed in the licensor's patent application constitutes the peripheral technology. ${ }^{21}$ Licensing allows the use of this knowledge without infringing the licensor's patent, which is enforceable in court. However, the licensor possesses more knowledge than disclosed in the patent, which cannot be readily defined and priced in the contract. The core technology contains this component. Consequently, what type of technology was actually transferred may not be easily verifiable in court. In this case, for the core technology to be transferred, the contract should be incentive compatible. The incentive compatibility constraint for the licensor to transfer the core technology is:

$$
\begin{aligned}
& R^{C O R E}(\mathrm{r})+\phi_{S}^{C O R E} \geq R^{P E R I}(\mathrm{r})+\phi_{S}^{P E R I}, \text { or } \\
& R^{C O R E}(\mathrm{r})-R^{P E R I}(\mathrm{r})=\mathrm{r}[\mathrm{q}(\underline{c}+\mathrm{r})-\mathrm{q}(\bar{c}+\mathrm{r})] \geq \theta \mathrm{V}=\phi_{S}^{P E R I}-\phi_{S}^{C O R E}
\end{aligned}
$$

In other words, the increase in royalty income by transferring the core technology should

\footnotetext{
${ }^{20}$ Caves et al. (1983) also note --but does not elaborate the point --that "[t]he very use of a royalty rate in technology licenses itself indicates a market imperfection in those cases where the licensee sells . monopolistically in a different market from the licensor."

${ }^{21}$ Indeed, one reason to grant patent protection is to accelerate aggregate innovations by inducing disclosure of inventions. Naturally, firms applying for patents try to minimize the amount of information disclosure to other rival firms. For an analysis of the relationship between the patent law and information disclosure, see Scotchmer (1991).
} 
be sufficiently large to overcome the decrease in the profit due to future competition. Note that if there is no future consideration due to the transfer of the core technology (i.e., $\phi_{S}^{P E R I}-\phi_{S}^{C O R E}=0$ ), the incompleteness of the contract does not cause any inefficiencies. Specifying any arbitrarily small royalty rate will make the transfer of the core technology to be incentive compatible. In other words, the possibility of future competition is a necessary condition for the failure of transferring the core technology to occur even though it alone cannot be a sufficient condition, as we have seen above in Proposition 3.

The effect of the royalty rate on the gap in royalty incomes between the core and the peripheral technologies can be derived as:

$$
\mathrm{d}\left[R^{C O R E}(\mathrm{r})-R^{P E R I}(\mathrm{r})\right] / \mathrm{dr}=[\mathrm{q}(\underline{c}+\mathrm{r})-\mathrm{q}(\bar{c}+\mathrm{r})]+\mathrm{r}\left[\mathrm{q}^{\prime}(\underline{c}+\mathrm{r})-\mathrm{q}^{\prime}(\bar{c}+\mathrm{r})\right]
$$

When (9) is evaluated at $r=0$, it is positive; the gap in royalty incomes increases at least initially as the royalty rate becomes positive. To avoid unnecessary complications, let me assume that $\sup \left[R^{C O R E}(\mathrm{r})-R^{P E R I}(\mathrm{r})\right]>\mathrm{V} .22$ This ensures that there exists a royalty rate $\mathrm{r}$ that can satisfy the ICC for all $\theta \in[0,1] . \quad$ Let $r^{*}(\theta)$ be the minimum royalty rate that satisfies the ICC. Note that the existence of a royalty rate that satisfies the ICC does not necessarily imply that the core technology will be transferred. The reason is that $r^{*}(\theta)$ is increasing in $\theta$, reflecting the fact that the ICC becomes more costly to satisfy as the possibility of leapfrogging increases. If the ICC is too costly to satisfy, the licensor may opt to transfer the peripheral technology.

When the core technology is transferred with royalty rate $r^{*}(\theta)$, the licensor extracts the payoff for the licensee via a fixed fee which is given by $\pi\left[\underline{c}+\mathbf{r}^{*}(\theta)\right]+\phi_{B}^{\text {CORE }}$ :

$$
F^{P E R U}=\pi\left[\underline{c}+\mathrm{r}^{*}(\theta)\right]+\phi_{B}^{C O R E}=\pi\left[\underline{c}+\mathrm{r}^{*}(\theta)\right]+\theta \mathrm{V}
$$

Therefore, given the probability of losing the future competition $\theta$, the payoff for the licensor from transferring the core technology can be written as:

${ }^{22}$ This assumption is made purely to simplify exposition and is not necessary. If this assumption is violated, there is a critical value $\bar{\theta}$ where $\sup \left[R^{C O R E}(\mathrm{r})-R^{P E R U}(\mathrm{r})\right]=\bar{\theta} \mathrm{V}$. Then, the incentive compatibility constraint can be met for all $\theta \leq \bar{\theta}$. All the analysis that follows, then, can be applied to this restricted region. 


$$
\begin{aligned}
\Pi^{\text {CORE }}(\theta) & =R^{C O R E}(\mathrm{r})+F^{C O R E}+\phi_{s}^{C O R E} \\
& =\mathrm{r}^{*}(\theta) \mathrm{q}\left[\underline{c}^{+} \mathrm{r}^{*}(\theta)\right]+\pi\left[\underline{c}+\mathrm{r}^{*}(\theta)\right]+\mathrm{V}
\end{aligned}
$$

When the peripheral technology is transferred, the payoff is the same as in the complete contract case since there is no additional incentive constraint to be satisfied.

$$
\Pi^{P E R I}(\theta)=R^{P E R I}(0)+F^{P E R I}+\phi_{S}^{P E R I}=\pi(\bar{c})+\mathrm{V}
$$

By using the envelope theorem, I can derive

$$
\frac{d \Pi^{C O R E}(\theta)}{d \theta}=\mathrm{r}^{*}(\theta) \mathrm{q}^{\prime}\left[\underline{c}+\mathrm{r}^{*}(\theta)\right] \mathrm{r}^{* \prime}(\theta)<0
$$

Since $\prod^{P E R l}(\theta)$ is constant and independent of $\theta$, there is a unique $\theta^{*}$ such that $\Pi^{C O R E}(\theta)>\Pi^{P E R I}(\theta)$ if and only if $\theta<\theta^{*}$. If no such $\theta^{*}$ exists, set $\theta^{*}=1$.

This result can explain why the transfer of the core technology will decrease as the capability of the licensee to develop a new product increases. It can also be shown that, given the ability of the licensee $\theta$, the ICC is more difficult to satisfy as V becomes larger. This implies that as the value of winning future competition becomes more important, the core technology will be transferred less often. These predictions are consistent with the protectionist arguments that advocate safeguarding the cutting-edge technology.

However, it is important to understand why transferring the core technology becomes less attractive for the licensor as the probability of leapfrogging and the value of future competition get larger. A simple explanation that the licensor gets more cautious in safeguarding her frontier technology to maintain her dominant position begs the question of why the expected loss of the licensor cannot be compensated via a fixed fee if the licensee's competitive gains come at the expense of the licensor. Indeed, in Proposition 3, I demonstrated that any loss of competitive edge that accompanies the transfer of the core technology can be compensated via a fixed fee. In my model, the reason lies in the cost of satisfying the ex post ICC due to the inability to write a complete contract. According to my model, therefore, it is not a mistake for the licensor to transfer the core technology even when she loses future competition to the licensee to whom her core technology has been transferred. It could have been a calculated risk taken by a 
rational decision-maker.

My model can also shed some light on the mechanism by which a "grant-back" clause can facilitate the transfer of the core technology; it relaxes the ICC. To analyze the effect of the grant-back clause on the incentive to transfer the core technology, let me assume that $V$ comprises two components, $V_{B}$ and $V_{S}\left(V=V_{B}+V_{S}\right)$. $\quad V_{B}$ and $V_{S}$ denote the values of the new product in the licensee's and licensor's local markets, respectively. The grant-back clause stipulates that any improvements derived from the licensed technology by the licensee be assigned to the licensor. However, they may be used by the licensee without any additional licensee fee or royalty (Areeda [1981]). In such an event, the licensor and licensee will capture their own local markets if we assume a Bertrand type competition and a small sunk cost of entry into the other's market. Therefore, with the inclusion of the "grant-back" clause in the licensing contract, the future payoffs from transferring the core technology are ${ }^{23}$ :

$$
\widetilde{\phi}_{S}^{\text {CORE }}=(1-\theta) \mathrm{V}+\theta \mathrm{V}_{\mathrm{S}}, \quad \widetilde{\phi}_{B}^{C O R E}=\theta \mathrm{V}_{\mathrm{B}}
$$

The future payoff from the peripheral technology is the same as before $\left(\widetilde{\phi}_{S}^{P E R I}=\phi_{S}^{P E R I}=\mathrm{V}\right.$, $\widetilde{\phi}_{B}^{\text {PERI }}=\phi_{B}^{P E R I}=0$ ) because the grant-back clause has no consequences in this case.

The ICC for the licensor to transfer the core technology can be rewritten as:

$$
\begin{aligned}
& R^{C O R E}(\mathrm{r})+\widetilde{\phi}_{S}^{C O R E} \geq R^{P E R I}(\mathrm{r})+\widetilde{\phi}_{S}^{P E R I}, \text { or } \\
& R^{C O R E}(\mathrm{r})-R^{P E R I}(\mathrm{r})=\mathrm{r}[\mathrm{q}(\underline{c}+\mathrm{r})-\mathrm{q}(\bar{c}+\mathrm{r})] \geq \theta \mathrm{V}_{\mathrm{B}}=\widetilde{\phi}_{S}^{P E R I}-\widetilde{\phi}_{S}^{C O R E}
\end{aligned}
$$

Let $\widetilde{r}^{*}(\theta)$ be the minimum royalty rate to satisfy the ICC given the probability of losing future competition $\theta$. Since the incentive compatibility has been relaxed with the grantback clause $\left(\mathrm{V}_{\mathrm{B}}<\mathrm{V}\right)$, we have $\widetilde{r}^{*}(\theta)<\mathrm{r}^{*}(\theta)$. The payoff from transferring the core technology can be written as:

$$
\widetilde{\Pi}^{\operatorname{CORE}}(\theta)=\pi\left[\underline{c}+\widetilde{r}^{*}(\theta)\right]+\widetilde{r}^{*}(\theta) \mathrm{q}\left[\underline{c}^{+} \widetilde{r}^{*}(\theta)\right]+\mathrm{V}
$$

The payoff from transferring the peripheral technology is the same as before:

$$
\widetilde{\Pi}^{P E R I}(\theta)=\Pi^{P E R I}(\theta)=\pi(\bar{c})+\mathrm{V}
$$

\footnotetext{
${ }^{23}$ Variables corresponding to the case with a grant-back clause are denoted with tilde.
} 
Let $\widetilde{\theta}^{*}$ be the unique value such that $\widetilde{\Pi}^{\text {CORE }}(\theta)>\widetilde{\Pi}^{P E R I}(\theta)$ if and only if $\theta<\widetilde{\theta}^{*}$. The fact that $\widetilde{r}^{*}(\theta)<\mathrm{r}^{*}(\theta)$ implies that $\widetilde{\theta}^{*}>\theta^{*}$. Consequently, grant-back clauses can be beneficial for the licensor in two respects. First, the grant-back clause allows the core technology to be transferred for a wider range of parameters. For parameter values $\theta \in$ $\left(\theta^{*}, \widetilde{\theta}^{*}\right]$, the core technology will not be transferred without the grant-back clause. Second, for $\theta<\theta^{*}$, the grant-back clause is not necessary for the core technology to be transferred. The grantback clause, however, reduces the royalty rate and induces a more efficient output level (see Figure 2).

Proposition 2. Inclusion of a royalty rate is necessary for the transfer of the core technology to be ex post incentive-compatible if the type of technology to be transferred cannot be specified in the contract. As the value of winning future competition becomes more important, the incentive compatibility constraint becomes more costly to satisfy. As a result, the transfer of core technology is observed less often. Grantback clauses allow the core technology to be transferred in a wider parameter space by relaxing the ICC.

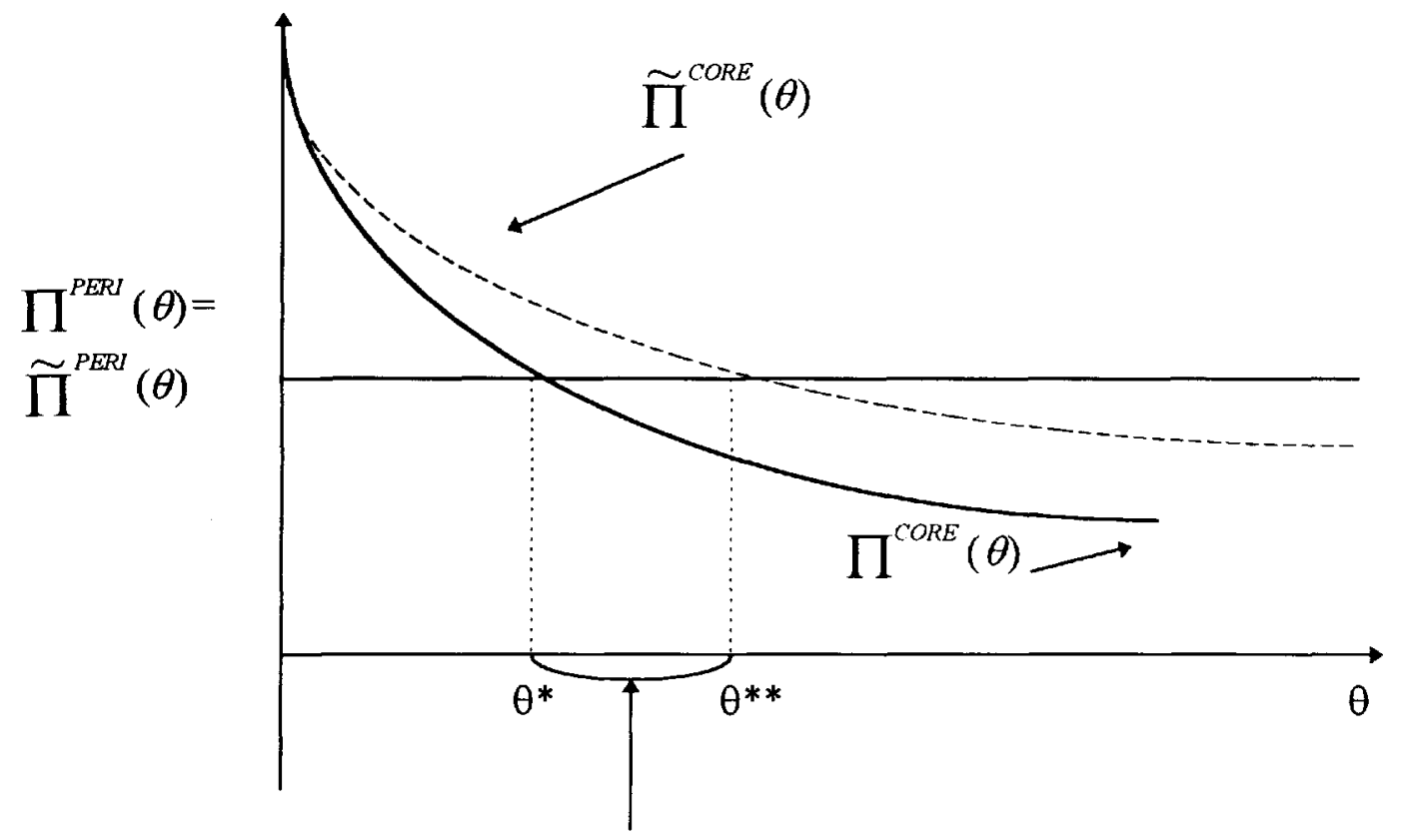

The parameter region in which the inclusion of the grant-back clause is needed for the core technology to be transferred.

Figure 2. The Effect of the Grant-Back Clause in the Licensing of the Core Technology 


\section{Grant-Back Clauses and R\&D Incentives}

The basic model in the previous section abstracted from two important considerations in the analysis of the grant-back clause. First, the model was devoid of any strategic $R \& D$ competition in that innovation was implicitly assumed to occur by chance. Therefore, the only effect of the grant-back clause was an indirect one; grantback clauses relax the ICC, which in turn affects the current production decision through the royalty rate. If I introduce $R \& D$ costs which vary with the intensity level, the inclusion of the grant-back clause may have the direct effect of dulling the incentive for the licensee to engage in $R \& D$. This reduction in $R \& D$ incentives for the licensee raised antitrust concerns that grantback clause may adversely affect competition by limiting rivalry in innovation markets (see, for instance, U.S. Department of Justice Antitrust Guidelines for the Licensing and Acquisition of Intellectual Property, 1994). In this section, I examine the validity of this concern on the anti-competitive effects of grantback clauses.

\section{A. Licensee 's R\&D Incentives with Grantback Clauses}

As in the previous section, I consider a two-period model in which each firm has a chance to conduct $R \& D$ at the end of the first period. Both firms simultaneously decide whether or not they will pursue R\&D. The value of R\&D for each firm, which depends on whether the grant-back clause is in place, is known to both firms. The cost of R\&D is randomly realized and depends on the technological capability of the firm. If a firm holds the core technology, the cost of developing a new generation of product is distributed according to $\mathrm{G}$. If a firm has the backwards technology, it is assumed that the firm does not possess the ability to develop a new product. ${ }^{24}$

Each firm's optimal R\&D policy is characterized by a cut-off point in R\&D costs. In this framework, there is a positive probability that both firms innovate, and thus the

\footnotetext{
${ }^{24}$ We can generalize the model by assuming that if the firm holds the peripheral technology, the cost is
} distributed according to $F$, which is assumed to be first-order stochastically dominated, that is, $F(x)<G(x)$. 
payoff structure needs to be specified when both firms innovate. I shall assume that each firm becomes a monopolist in its own market with the payoffs of $V_{S}$ and $V_{B}$ for the licensor and the licensee, respectively. It transpires that nothing of analytical substance depends on this particular assumption. For instance, I can also assume that the winner is determined randomly with an equal probability in the case of multiple innovators.

Let me first analyze the licenser's incentive to engage in R\&D. Suppose that the licensor's probability of developing a new product is given by $\sigma$. Without a grantback clause, the licensee's expected payoff from engaging in R\&D is given by $\sigma V_{B}+(1-\sigma) V$ $c=V_{B}+(1-\sigma) V_{S}-c$, while its expected payoff is zero without $R \& D$. Thus, $R \& D$ is undertaken by the licensee if and only if

$$
\mathrm{c} \leq c_{B}^{*}=\mathrm{V}_{\mathrm{B}}+(1-\sigma) \mathrm{V}_{\mathrm{S}}
$$

With a grantback clause, the licensee yields the right to use the licensee's innovation in the licensor's market. Therefore, the expected payoff of $R \& D$ is $V_{B}-c$. Thus, $R \& D$ is undertaken if and only if

$$
\mathrm{c}<\widetilde{c}_{B}^{*}=\mathrm{V}_{\mathrm{B}}
$$

Note that the licensee's cutoff level of R\&D costs under the grantback clause $\left(\widetilde{c}_{B}{ }^{*}\right)$ is independent of the R\&D behavior of the licensor and is unambiguously lower than the cutoff level without a grantback clause $\left(c_{B}{ }^{*}\right)$, implying that the licensee has less incentive to engage in R\&D. This result, thus, confirms the validity of the concern that grantback clauses can reduce the licensee's incentive to engage in R\&D.

\section{B. The Welfare Implications of the Grantback Clauses}

The welfare implications of the grantback clauses are not necessarily anticompetitive due to the licensee's reduced $R \& D$ incentives for the following reasons:

\section{Enhanced R\&D Capability with Grantback Clauses}

Grantback clauses can enhance the efficacy of the licensee's R\&D spending by transferring a more advanced technology. If the prohibition of the grant-back clause 
results in the licensing of the backward technology instead of the advanced technology, grantback clauses can eliminate wasteful and inefficient research expenditures. This point is clearly manifested in my model because no innovation can be forthcoming from the licensee with the peripheral technology; less $R \& D$ is better than no R\&D at all. ${ }^{25}$

\section{Licensor's R\&D Incentives}

When the licensor and the licensee are engaged in strategic R\&D competition, the licensor's response to the licensee's reduced R\&D incentives should be taken into account. In particular, it is possible that licensor may increase her own R\&D efforts in response to the reduced R\&D efforts of the licensee. This is especially true, if the nature of $R \& D$ competition is such that $R \& D$ decisions are strategic substitutes (Bulow, Geanokopolis, and Klemperer, 1986). To see this possibility, let me first analyze the licensor's incentive to engage in R\&D. Suppose that the licensee's probability of developing a new product is given by $\beta$. Without a grantback clause, the licenses expected payoff from engaging in $R \& D$ is given by $\beta V_{S}+(1-\beta) V-c$ while its expected payoff is zero without $R \& D$. Therefore, $R \& D$ is undertaken by the licensor if and only if

$$
c<c_{S}^{*}=\beta V_{S}+(1-\beta) V
$$

With a grantback clause, let the licensee's probability of developing a new product be given by $\widetilde{\beta}$. With a grantback clause, the licensor gets the expected payoff of $\widetilde{\beta} \mathrm{V}_{\mathrm{S}}$ even without her own $R \& D$. When the licensor engages in $R \& D$, its expected payoff is given by $\widetilde{\beta} V_{S}+(1-\widetilde{\beta}) \mathrm{V}-\mathrm{c}$. Thus, R\&D is undertaken by the licensor if and only if

$$
\mathrm{c} \leq \widetilde{c}_{S}^{*}=(1-\widetilde{\beta}) \mathrm{V}
$$

A comparison of conditions (16) and (17) indicates that the licensor's R\&D incentives are altered with the grantback clauses in two ways. First, if the $R \& D$ incentives for the licensee is the same, that is $\beta=\widetilde{\beta}$, the licensor will reduce its $R \& D$ because it now can appropriate partial benefits of the licensee's R\&D outcome. However, we know that the

${ }^{25}$ Even if innovation is possible with the peripheral technology, the effective level of R\&D may be still higher with grantback clauses as long as I retain the assumption that further innovation is facilitated with the transfer of the core technology. 
licensee's $\mathrm{R} \& \mathrm{D}$ is reduced as a result of the grantback clause (i.e, $\widetilde{\beta}=\mathrm{G}\left(\widetilde{c}_{B}{ }^{*}\right)<\mathrm{G}\left(c_{B}{ }^{*}\right)$ $=\beta$ ), which induces the licensor to increase her own $R \& D$ in response. The direction of the overall effect of the grantback clause on the licensor's R\&D incentives will thus depend on the relative magnitude of these two opposing effects.

\section{Preemptive R\&D with Parallel Research}

The licensee's reduced R\&D incentives may be beneficial if unbridled $R \& D$ competition between the licensor and the licensee tends to excessive and rent-dissipating. It is well-known in the literature that the winner-takes-all payoff structure of the R\&D game often implies excessive rent dissipation. In this case, restrained competition with grantback clauses may also be socially beneficial.

\section{The Analysis of a Specific Model}

To further analyze the welfare implications of the grantback clause and identify the conditions for which the grantback clause may be welfare improving or reducing, let me assume a specific form of cost distribution.

Let the cost of R\&D be distributed uniformly between $[0, n V]$ if the firm has the core technology, where $\mathrm{n} \geq 1$, i.e., $\mathrm{G}(\mathrm{x})=\mathrm{x} / n \mathrm{~V}, \mathrm{x} \in[0, n \mathrm{~V}]$. I can interpret $n$ as a parameter indicating the difficulty of the $R \& D$ project. Let me further assume that the licensor and the licensee have the same market size, namely, $V_{S}=V_{B}=V / 2$.

\section{With Grantback Clauses}

We know that the licensee's critical value of $R \& D$ cost is $\widetilde{c}_{B} *=V_{B}=V / 2$ (see Eq. (14)). Therefore, the probability that the licensee will develop a new product is given by $\widetilde{\beta} *=\mathrm{G}\left(\widetilde{c}_{B} *\right)=1 / 2 \mathrm{n}$. Given this, the licensor's critical value is given by $\widetilde{c}_{S}^{*}=(1-\widetilde{\beta})$ $\mathrm{V}=\left(1-\frac{1}{2 n}\right) \mathrm{V}$. The probability that the licensor will engage in $\mathrm{R} \& \mathrm{D}$ is given by $\tilde{\sigma}^{*}=$ $\mathrm{G}\left(\widetilde{c}_{s}^{*}\right)=\frac{2 n-1}{2 n^{2}}$. The expected welfare from the R\&D game between the licensor and licensee is: 


$$
\begin{aligned}
\tilde{\mathrm{W}}^{\mathrm{CORE}} & =\left[1-\left(1-\tilde{\beta}^{*}\right)\left(1-\tilde{\sigma}^{*}\right)\right] \mathrm{V}-\int_{0}^{\tilde{c}_{B}^{*}} x d G-\int_{0}^{\tilde{c}_{s}^{*}} x d G \\
& =\left[\frac{1}{2 n}+\frac{(n-1)(3 n-1)}{8 n^{3}}\right] \mathrm{V}
\end{aligned}
$$

\section{Without Grantback Clauses}

Without grantback clauses, I consider two possible scenarios, depending on which type of technology is transferred, in light of the results in the previous section.

\section{Case 1. The Transfer of the Peripheral Technology}

In this case, the licensee firm has no capability to develop the new product, that is, $\beta^{*}=0$. The licensor's R\&D incentives are characterized by $c_{s}^{*}=\mathrm{V}$ with $\sigma^{*}=1 / \mathrm{n}$. The expected social welfare in this case is:

$$
\mathrm{W}^{\mathrm{PERI}}=\sigma^{*} \mathrm{~V}-\int_{0}^{c s^{*}} x d G=\frac{1}{2 n} \mathrm{~V}\left(<\widetilde{\mathrm{W}}^{\mathrm{CORE}}\right)
$$

Thus, if the consequence of excluding grantback clauses is the transfer of the peripheral technology, the welfare from $R \& D$ is unambiguously reduced without grantback clauses.

\section{Case 2. The Transfer of the Core Technology}

Suppose that the core technology is still transferred without a grantback clause. In this case, both firms are symmetrically situated without the grantback clause. I will focus on the symmetric equilibrium in the R\&D game. Let $c_{S} *=c_{B} *=\mathrm{c}^{*}$ be the common critical value for the licensor and licensee in their decision on R\&D. Let $\mu^{*}$ be the corresponding probability of developing the new product for each firm, that is $\mu^{*}=\beta^{*}=$ $\sigma^{*}=\mathrm{G}\left(\mathrm{c}^{*}\right)$

To derive the symmetric equilibrium, let $\sigma$ be the licensor's probability of developing a new product. Then, the licensee's critical value of cost realization is defined by:

$$
\sigma\left(\frac{1}{2} \mathrm{~V}\right)+(1-\sigma) \mathrm{V}=c_{B}
$$


Therefore, the probability for the licensee to develop the new product is given by

$$
\beta=\mathrm{G}\left(c_{B}\right)=\mathrm{G}\left[\sigma\left(\frac{1}{2} \mathrm{~V}\right)+(1-\sigma) \mathrm{V}\right]=\frac{1}{n}\left[\frac{1}{2} \sigma+(1-\sigma)\right]
$$

At the symmetric equilibrium, $\sigma^{*}=\beta^{*}$.

Thus, I have

$$
\begin{aligned}
& \mu^{*}=\sigma^{*}=\beta^{*}=\frac{2}{2 n+1} \\
& \mathrm{c}^{*}=c_{S}^{*}=c_{B}^{*}=\frac{2 n}{2 n+1} \mathrm{~V}
\end{aligned}
$$

The expected welfare from the $\mathrm{R} \& \mathrm{D}$ game is given by:

$$
\begin{aligned}
\mathrm{W}^{\mathrm{CORE}} & =\left[1-\left(1-\mu^{*}\right)^{2}\right] \mathrm{V}-2 \int_{0}^{\mathcal{C}_{B}{ }^{*}} x d G \\
& =\frac{4 n}{(2 n+1)^{2}} \mathrm{~V}
\end{aligned}
$$

Comparison of $\mathrm{W}^{\mathrm{CORE}}$ and $\widetilde{\mathrm{W}}^{\mathrm{CORE}}$ indicates that $\widetilde{\mathrm{W}}^{\mathrm{CORE}} \geq \mathrm{W}^{\mathrm{CORE}}$ if and only if $n \leq \bar{n} \approx$ 2.5195. Since $n$ is a parameter for the difficulty of the research project, the result has a natural interpretation. When the innovation is more or less certain (for a small $n$ ), the beneficial effect of diversified research is rather small and is outweighed by the cost of duplication and excessive $R \& D$. Thus, the reduced $R \& D$ with a grantback clause can be beneficial. However, when the R\&D is difficult, the beneficial effect of diversification through parallel research is more important.

Proposition 3. (1)If the grantback clause induces the transfer of the core technology, the inclusion of a grantback clause increases the industry rent from R\&D. (2)If the core technology is transferred irrespective of the inclusion of the grant-back clause, the effect of the grantback clause on the industry rent can be either positive or negative. If $n$ is small $(n \leq \bar{n}$ ), that is $\mathrm{R} \& \mathrm{D}$ tends to be duplicative, the effect of the grantback clause is positive because it can mitigate excessive $R \& D$. Otherwise, the effect is negative because the benefit of diversification outweighs the cost of duplication. 


\section{The Optimal Contract with R\&D Competition}

If the licensing contract can specify which type of technology will be transferred, the optimal contractual form will be the one which generates the maximum industry rent from the $R \& D$ game since any rent created in the $R \& D$ game can be extracted by the licensor by a lump-sum payment. Then, it is immediate that the core technology will always be transferred since the transfer of the peripheral technology is strictly dominated by a contract that transfers the core technology with a grantback clause $\left(\mathrm{W}^{\mathrm{PERI}}<\widetilde{\mathrm{W}}^{\text {CORE}}\right.$, see Eq. (19)). This does not necessarily imply that the grantback clause will always be included in the contract. Proposition 3 in the previous section informs us that whether or not the contract will actually include a grantback clause will depend on, inter alia, the difficulty of the project parametrized by $n$.

If the contract cannot specify the type of technology transferred, however, the cost of satisfying the incentive constraint should also be taken into account in the choice of optimal contract. More specifically, we already know that the expected value for the licensor when she transfers the peripheral technology is given by:

$$
\phi_{S}^{\text {PERI }}=\mathrm{W}^{\mathrm{PERI}}=\frac{1}{2 n} \mathrm{~V}
$$

When the core technology is transferred, the expected value for the licensor depends on whether or not a grant back clause is included in the contract. Without a grantback clause, the two firms are in a symmetric position and share the industry rent equally. Thus, the expected value of $R \& D$ game for the licensor is given by:

$$
\phi_{S}^{\text {CORE }}=\frac{1}{2} \mathrm{~W}^{\mathrm{CORE}}=\frac{2 n}{(2 n+1)^{2}} \mathrm{~V}
$$

Note that $\phi_{S}^{\text {PERI }}>\phi_{S}^{C O R E}$. Thus, for the transfer of the core technology to be incentive compatible, a royalty rate should be part of the contract:

$$
R^{C O R E}(\mathrm{r})-R^{P E R I}(\mathrm{r})=\mathrm{r}[\mathrm{q}(\underline{c}+\mathrm{r})-\mathrm{q}(\bar{c}+\mathrm{r})] \geq\left[\frac{1}{2 n}-\frac{2 n}{(2 n+1)^{2}}\right] \mathrm{V}=\phi_{S}^{P E R I}-\phi_{S}^{C O R E}
$$

I can define $\mathrm{r}^{*}(n)$ as the minimal royalty rate that satisfies the above constraint. 
In contrast, with the grantback clause the expected value for the licensor is given

by

$$
\begin{aligned}
\widetilde{\phi}_{S}^{C O R E} & =\widetilde{\beta}^{*} \mathrm{~V}_{\mathrm{S}}+\tilde{\sigma}^{*}\left(1-\tilde{\beta}^{*}\right) \mathrm{V}-\int_{0}^{\tilde{c}_{s}^{*}} x d G \\
& =\left[\frac{1}{4 n}+\frac{1}{2 n}\left(1-\frac{1}{2 n}\right)^{2}\right] \mathrm{V}
\end{aligned}
$$

As in section II, if the peripheral technology is transferred, there is no effect of the grantback clauses on the R\&D competition. Thus, $\widetilde{\phi}_{S}^{\text {PERI }}=\phi_{S}^{\text {PERI }}$. For the transfer of the core technology to be incentive compatible with the grantback clause, it is required that:

$$
R^{C O R E}(\mathrm{r})-R^{P E R I}(\mathrm{r})=\mathrm{r}[\mathrm{q}(\underline{c}+\mathrm{r})-\mathrm{q}(\bar{c}+\mathrm{r})] \geq\left[\frac{-2 n^{2}+4 n-1}{8 n^{3}}\right] \mathrm{V}=\widetilde{\phi}_{S}^{P E R I}-\widetilde{\phi}_{S}^{C O R E}
$$

Let $\widetilde{r}^{*}(n)$ be the minimum royalty that satisfies the constraint ( $\left.8 \mathrm{a}\right)^{\prime}$. It can be easily verified that $\widetilde{\phi}_{S}^{P E R I}-\widetilde{\phi}_{S}^{C O R E}<\phi_{S}^{P E R I}-\phi_{S}^{C O R E}$. This implies that the incentive to cheat is less under the grantback clause, and thus $\widetilde{r}^{*}(n)<\mathrm{r}^{*}(n)$; the grantback clause relaxes the incentive constraint as in Section II. Moreover, there is a critical value $n^{\text {IC }}$ such that if $n \geq$ $n^{\mathrm{IC}} \approx 1.707, \widetilde{\phi}_{S}^{\text {PERI }}-\widetilde{\phi}_{S}^{\mathrm{CORE}}<0$. That is, if $n \geq n^{\mathrm{IC}}$, the ICC is irrelevant and the core technology can be transferred without any royalty rate. The intuition is that if $n$ is sufficiently large, the probability of duplication is small, and it is in the best interest of the licensor to diversify the opportunity of R\&D and reap the partial benefit of the licensor's innovation through the grantback clause.

Since the licensor is assumed to have all the bargaining power and a lump sum payment can be used to extract all the surplus for the licensee, we have

$$
\begin{aligned}
& \prod^{\text {CORE }}(n)=\mathrm{r}^{*}(n) \mathrm{q}\left[\underline{c}+\mathrm{r}^{*}(n)\right]+\pi\left[\underline{c}+\mathrm{r}^{*}(n)\right]+\mathrm{W}^{\text {CORE }} \\
& \widetilde{\Pi}^{\text {CORE }}(n)=\widetilde{r}^{*}(n) \mathrm{q}\left[\underline{c}+\widetilde{r}^{*}(n)\right]+\pi\left[\underline{c}+\widetilde{r}^{*}(n)\right]+\widetilde{\mathrm{W}}^{\mathrm{CORE}} \\
& \prod^{\text {PERI }}(n)=\pi(\bar{c})+\mathrm{W}^{\mathrm{PERI}}
\end{aligned}
$$

Comparisons of Eqs. (11)', (11a)', and (12)' give us the following results: First, if $n \geq n^{\mathrm{C}}$, the core technology will be transferred. The reason is that when $n \geq n^{\text {rc }}$, the ICC is not binding and $\widetilde{r}^{*}(n)=0$. As a result, $\widetilde{\Pi}^{\text {CORE }}(n)=\pi(\underline{c})+\widetilde{\mathrm{W}}^{\text {CORE }}>\pi(\bar{c})+\mathrm{W}^{\mathrm{PERI}}$ 
$=\Pi^{P E R I}(n)$ (see Eq. (19)). Therefore, the transfer of the core technology with the grantback clause dominates the transfer of the peripheral technology. However, if $n$ is sufficiently small $\left(n<<n^{\mathrm{IC}}\right)$ it may be too costly to satisfy the ICC, and the licensor may opt to transfer the peripheral technology. Second, for the core technology to be transferred without grantback clause, it is necessary that $n>\bar{n}$. To see this, note that $\widetilde{r}^{*}(n)<\mathrm{r}^{*}(n)$. This implies that $\mathrm{r}^{*}(n) \mathrm{q}\left[\underline{c}+\mathrm{r}^{*}(n)\right]+\pi\left[\underline{c}^{+}+\mathrm{r}^{*}(n)\right]<\widetilde{r} *(n) \mathrm{q}\left[\underline{c}+\tilde{r}^{*}(n)\right]+$ $\pi\left[\underline{c}+\widetilde{r}^{*}(n)\right]$ (see Eq. (13)). Therefore, for $\Pi^{C O R E}(n)>\widetilde{\Pi}^{\text {CORE }}(n)$, it is required that $\mathrm{W}^{\mathrm{CORE}}>\widetilde{\mathrm{W}}^{\mathrm{CORE}}$. By using the continuity argument, I can state that there exist $\widetilde{n}\left(<n^{\mathrm{IC}}\right)$ and $\widetilde{n}(>\bar{n})$ such that the transfer of the core technology with a grantback clause is optimal at least for $n \in[\widetilde{n}, \widetilde{\tilde{n}}]$.

Proposition 4. (1)The optimal contract transfers the core technology with the inclusion of the grantback clause for intermediate values of $n$ (i.e., $n \in[\widetilde{n}, \widetilde{\tilde{n}}]$ ). For $n \in\left[\widetilde{n}, n^{\mathrm{IC}}\right]$, the contract also includes a positive royalty rate. For $n \in\left(n^{i c}, \widetilde{\tilde{n}}\right]$, the contract has only the lump-sum component. (2)For $n<\widetilde{n}$, it is possible that only the peripheral technology is transferred with a lump-sum contract since the cost of the ICC is too high. (3)For $n$ $>\widetilde{\widetilde{n}}$, the optimal contract can be the transfer of the core technology without the grantback clause because the diversification of R\&D is more important. In this case, the optimal contract includes a positive royalty rate to satisfy the ICC constraint. A typical case for the configuration of the optimal contract is shown in Figure 3.

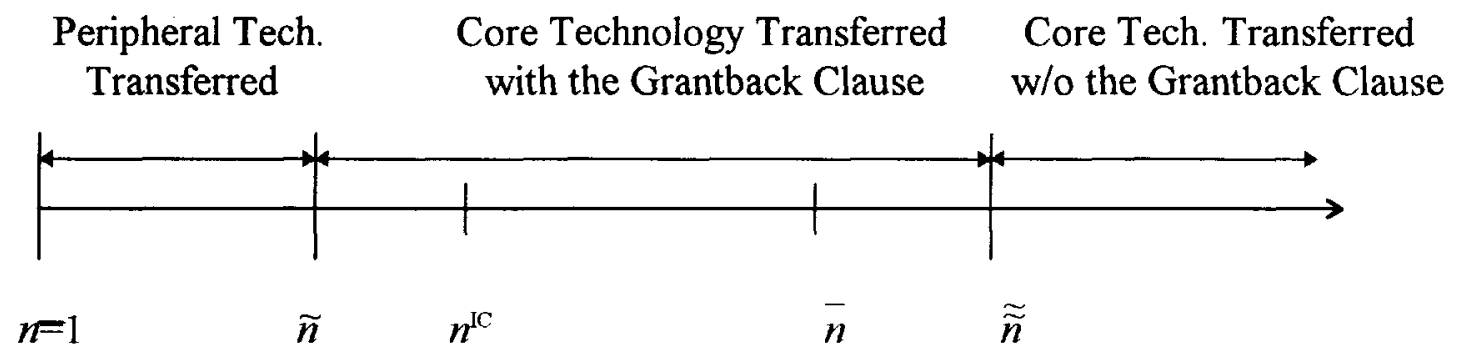

Figure 3. The Optimal Contracts with R\&D Competition 
Up to now, I have analyzed the licensor's private incentive to include the grantback clause in the contract. I compare the private incentives to that of the social planner's who can only control the inclusion of the clause; R\&D decisions and other aspects of the contract are left to the firms. To this purpose, let me define social welfare as the sum of industry profits and consumer surplus. Let $\mathrm{CS}(\mathrm{c})$ denote consumer surplus in the licensee market with $\operatorname{CS}^{\prime}(c)<0$. Then, the grantback clause is included in the contract by the licensor if

$$
\widetilde{\Pi}^{C O R E}(n)>\max \left[\Pi^{C O R E}(n), \Pi^{P E R I}(n)\right]
$$

In contrast, the social surplus is maximized with the grantback clause if

$$
\widetilde{\Pi}^{\mathrm{CORE}}(n)+\operatorname{CS}\left[\underline{c}^{+} \tilde{r}^{*}(n)\right]>\max \left[\Pi^{\mathrm{CORE}}(n)+\operatorname{CS}\left[\underline{\underline{c}}+\mathrm{r}^{*}(n)\right], \Pi^{P E R I}(n)+\operatorname{CS}(\bar{c})\right]
$$

Note that

$$
\left[\widetilde{\Pi}^{C O R E}(n)-\Pi^{C O R E}(n)\right]<\left[\widetilde{\Pi}^{C O R E}(n)+\operatorname{CS}\left[\underline{c}^{+} \widetilde{r}^{*}(n)\right]\right]-\left[\Pi^{C O R E}(n)+\operatorname{CS}\left[\underline{c}+\mathrm{r}^{*}(n)\right]\right]
$$

Therefore, when I consider a situation under which the core technology is transferred irrespective of the inclusion of the grantback clause, the market incentive to include the grantback clause is less than the social planner's. Thus, whenever the grantback clause is included in the market, it is welfare improving; not only does it increase the industry rent from the R\&D game but it also increases the consumer surplus in the current period by relaxing the ICC and lowering the effective cost of the licensee. I conclude that there is less incentive to include the grantback clause in this case because the positive externality of lowering the royalty rate on consumer surplus is ignored by the private decision maker, whereas the impact of the grantback clause on the industry rent is fully accounted for.

However, if I consider the possibility that the peripheral technology is transferred without the grantback clause, I cannot rule out the case where the core technology is transferred with the grantback clause in the market, whereas the social welfare would be maximized when the peripheral technology is transferred:

$$
\begin{gathered}
\widetilde{\Pi}^{C O R E}(n)>\max \left[\Pi^{C O R E}(n), \Pi^{P E R l}(n)\right] \\
\Pi^{P E R l}(n)+\operatorname{CS}(\bar{c})>\max \left[\widetilde{\Pi}^{C O R E}(n)+\operatorname{CS}\left[\underline{c}^{+} \widetilde{r}^{*}(n)\right], \Pi^{C O R E}(n)+\operatorname{CS}\left[\underline{c}^{+}(n)\right]\right]
\end{gathered}
$$


This case can occur when $\widetilde{r}^{*}(n)>\bar{c}-\underline{c}$, making the effective cost of the licensee higher when the core technology is transferred $\left(\underline{c}+\widetilde{r}^{*}(n)>\bar{c}\right)$. Thus, the current consumers in the licensee's market buy at a higher price than when the peripheral technology is transferred. In this case, the prohibition of the grantback clause can be welfare improving if the peripheral technology is transferred in the market without the availability of the clause, i.e., $\Pi^{P E R I}(n)>\Pi^{C O R E}(n)$; without the grantback clause, the cost of satisfying the ICC is too high and the licensor transfers the peripheral technology. Interestingly enough, in this case, the anti-competitive effect of the grantback clause takes place through the current product market price rather than through the rivalry in the innovation market. In fact, the innovation market rivalry is intensified due to the grantback clause in this case since the alternative is the transfer of the peripheral technology. Thus, if there is any anti-competitive effect of the grantback clause, the emphasis on its effect on the innovation market may be misplaced.

With a simple model of R\&D, I analyzed the incentive to include the grantback clause in the licensing contract and its impact on the subsequent R\&D game. The inclusion of the grantback clause and the transfer of the core technology vis-à-vis the peripheral technology were shown to depend on the tradeoff between duplication and diversification in the R\&D process (parametrized by $n$ ) and the cost of satisfying the ICC. This general intuition should be robust to changes in the specifics of $R \& D$ game. For instance, even if I analyze the optimal contract in a fully dynamic R\&D race that accounts for the stochastic discovery process and discounting, the same type of results is expected. However, for the anti-competitive effect of the grantback clause, the result should be viewed as tentative. The crucial assumption in my analysis has been that the value of innovation for the society is the same as the private value of innovation (V). If the innovating firm cannot perfectly price discriminate and thus extract the consumer surplus resulting from the innovation, the private firms can underestimate the value of the innovation. This introduces a wedge between the social surplus and the industry rent. If 
this discrepancy is sufficiently large, it should be taken into account in the welfare analysis.

\section{Concluding Remarks}

In this paper, I analyze the licensing relationship under circumstances in which the nature of the knowledge to be transferred is not well-defined in that it cannot be specified exactly in the contract. I use the incomplete contract approach that accounts for this type of market imperfection to assess the dynamic effects of licensing on the R\&D competition in the innovation market. In particular, I analyze how the optimal contractual form of licensing should be structured and what the role of grant-back clauses are when licensing entails the risk of commissioning a competitor in the innovation market. The result is a framework that brings the model of licensing closer to reality in that it explains the prevalence of royalty contracts in the licensing relationship. ${ }^{26}$ I also evaluate the validity of the antitrust concern that grantback clauses may adversely affect competition because they reduce the licensee's incentive to engage in $R \& D$ and thereby limit rivalry in innovation markets.

Let me conclude by suggesting a couple of directions for future research. First, the framework developed in this paper may be useful in analyzing the issue of technology licensing and competitiveness in the global economy. In particular, my model may have implications for the dynamics in the formulation and implementation of technology policy for developing countries, which often pursue active government policies aimed at the creation of indigenous capacity. In fear of foreign dependency and/or for the purpose of strengthening the bargaining power of domestic firms, governments often require their own approval of foreign licensing agreements. In the approval process, governments restrict the type of contracts in order to preclude constraints that may be imposed by foreign nationals on local firms' efforts to develop their own capability. However, as the economy matures and threatens to be a competitor to potential licensors, it may even be

\footnotetext{
${ }^{26}$ Royalty-based licensing contracts can be also explained by such factors as signaling (Gallini and Wright, 1990), intertemporal tradeoffs (Contractor, 1981) and risk sharing.
} 
necessary to allow foreign suppliers greater control and favorable terms in order to have any chance of securing continued access to advanced foreign technologies; it may be counterproductive to insist on restrictive technology policy as the economy matures. In this respect, it is illuminating to observe that in the beginning of 1980 Korea abolished all restrictions imposed on terms and conditions of foreign licensing as it found it increasingly difficult to obtain state-of-the-art technologies [see Kim and Dahlman (1992)]. ${ }^{27}$

In order to focus on the implications of the licensee's enhanced capability to innovate for the competition in the innovation market, I assumed that the technology licensed in the first period becomes obsolete for sure in the next period. As a result, I deliberately ignored the "replacement effect" of the payoffs in the current period on the incentive to innovate, which was the main concern in the innovation literature [see, for example, Reinganum (1985), Gallini (1984), and Gallini and Winter (1985), etc.]. I also abstracted from the product market competition by considering licensing relationship between two firms serving segmented markets. Thus, absent in my model is the effect of payoff interdependence that can arise from downstream competition between the licensor and licensee or among potential licensees [see, for example, Katz and Shapiro (1985), Kamien and Tauman (1986), Gallini and Winter (1985), etc.]. To incorporate these distinct but complementary approaches into the framework would be a logical step for future research.

\footnotetext{
${ }^{27}$ In the face of increasing reluctance to transfer technology by firms in industrially-advanced countries, Korean firms also resorted to the strategy of setting up "antennas" which serve as technological outposts. For example, several Korean firms (especially major chaebols) have set up outposts in Silicon Valley to leapfrog into state-of-the-art technologies by monitoring technological changes and to acquire advanced semiconductor and computer technologies [see Kim (1993)].
} 


\section{References}

Aghion, Philippe and Patrick Bolton, "An Incomplete Contract Approach to Financial Contracting," Review of Economic Studies, LIX (1992), 473-94.

Aghion, Philippe and Jean Tirole, "The Management of Innovation, " Quarterly Journal of Economics, 1994, 1185-1209.

Areeda, Phillip, Antitrust Analysis, Little, Brown and Company, Boston, 1981.

Arrow, Kenneth, "Economic Welfare and the Allocation of Resources for Inventions," in Richard Nelson (ed.), The Rate and Direction of Inventive Activity, Princeton University Press, 1962.

Berrill, K. (ed.), Economic Development with Special Reference to East Asia, St. Martin Press, New York, 1964.

Bhattacharyya, Sugato and Francine Lafontaine, "Double-Sided Moral Hazard and the Nature of Share Contracts," Rand Journal of Economics (26), 1995, 761-781.

Bulow, Jeremy, John Geanakoplos, and Paul Klemperer, "Multimarket Oligopoly: Strategic Substitutes and Complements," Journal of Political Economy (93), 1985, 488-511.

Caves, R., Crookell, H. and J.P. Killing, The Imperfect Market for Technology Licenses," Oxford Bulletin of Economics and Statistics (45), 1983, 223-248.

Choi, Jay P., "Technology Transfer with Moral Hazard," unpublished manuscript, 1995.

Coase, Ronald, "The Problem of Social Cost," Journal of Law and Economics (3), 1960, $1-44$.

Cohen, Wesley M. and Daniel A. Levinthal, "Innovation and Learning: The Two Faces of R\&D," Economic Journal (99), 1989, 569-596.

Contractor, Farok J., International Technology Licensing, Lexington Books, 1981.

Davies, Howard, "Technology Transfer through Commercial Transactions," Journal of Industrial Economics (26), 1977, 161-175.

Dratler, Jay, Jr., Licensing of Intellectual Property, New York, Law Journal SeminarsPress, 1994.

Fershtman, Chaim and Morton I. Kamien, "Cross Licensing of Complementary Technologies," International Journal of Industrial Organization (10), 1992, 329348. 
Firestone, O., Economic Implications of Patents, University of Ottawa Press, 1971.

Gallini, Nancy T., "Deterrence through Market Sharing: A Strategic Incentive for Licensing," American Economic Review (74), 1984, 931-941.

Gallini, Nancy T., and Ralph Winter, "Licensing in the Theory of Innovation," Rand Journal of Economics (16), 1985, 237-252.

Gallini, Nancy T. and Brian D. Wright, "Technology Transfer under Asymmetric Information," Rand Journal of Economics (21), 1990, 147-160.

Green, Jerry and Suzanne Scotchmer, "On the Division of Profit in Sequential Innovation," Rand Journal of Economics (26), 1995, 20-33.

Grossman, Gene M. and Carl Shapiro, "Dynamic R\&D Competition," Economic Journal (97), June 1987, 372-387.

Grossman, Sanford and Oliver Hart, "The Costs and Benefits of Ownership: A Theory of Lateral and Vertical Integration, Journal of Political Economy (94), 1986, 691-719.

Kamien, Morton I., "Patent Licensing," in Robert J. Aumann and Sergiu Hart (ed.), Handbook of Game Theory, Vol.1, Elsevier Science Publishers B.V., 1992.

Kamien, Morton I. and Yair Tauman, "Fees versus Royalties and the Private Value of a Patent," Quarterly Journal of Economics (101), 1986, 471-491.

Katz, Michael and Carl Shapiro, "On the Licensing of Innovations," Rand Journal of Economics (16), 1985, 504-520.

Katz, Michael and Carl Shapiro, "R\&D Rivalry with Licensing or Imitation," American Economic Review (77), 1987, 402-420.

Kim, Linsu, "Absorptive Capacity and Industrial Growth: A Conceptual Framework and Korea's Experience," East Asian Institute Reports, Columbia University, March 1993.

Kim, Linsu and Carl J. Dahlman, "Technology Policy for Industrializatio: An Integrative Framework and Korea's Experience," Research Policy (21), 1992, 437-452.

Reinganum, Jennifer, "Innovation and Industry Evolution," Quarterly Journal of Economics (100), 1985, 81-100.

Roberts, Edward B. and Ryosuke Mizouchi, "Inter-Firm Technological Collaboration: The Case of Japanese Biotechnology," MIT Sloan School of Management Working Paper \#2034-88, 1988. 
Rockett, Katherine, "The Quality of the Licensed Technology," International Journal of Industrial Organization (8), 1990, 559-574.

Romano, Richard E., "Double Moral Hazard and Resale Price Maintenance," Rand Journal of Economics (25), 1994, 455-466.

Rostoker, M., "A Survey of Corporate Licensing," IDEA (24), 1984, 59-92.

Rothstein, Paul M. and Eric H. Willgohs, "Summary of Proceedings of the Symposium on the Law and Economics of International Technology Licensing," Stanford Journal of International Low (25), 1988, 231-256.

Scotchmer, Suzanne, "Standing on the Shoulders of Giants: Cumulative Research and the Patent Law," Journal of Economic Perspective (5), 1991, 29-41.

Shapiro, Carl, "Patent Licensing and R\&D Rivalry," American Economic Review (75), 1985, pp.25-30.

Teece, David J., "Technology Transfer by Multinational Firms: The Resource Cost of Transferring Technological Know-How," Economic Journal (87), 1977, 242-61.

Teece, David J., "Profiting from Technological Innovation: Implications for Integration, Collaboration, Licensing and Public Policy," Research Policy (15), 1986, pp. 285305 .

U.S. Department of Justice, "Antitrust Guide Lines for the Licensig and Acquisition of Intellectual Property," 7 Trade Reg. Rep. (CCH), 1994. 


\title{
1996-1997 Discussion Paper Series
}

\author{
Department of Economics \\ Columbia University \\ 1022 International Affairs Bldg. \\ 420 West 118th Street \\ New York, N.Y., 10027
}

The following papers are published in the 1996-97 Columbia University Discussion Paper series which runs from early November to October 31 of the following year (Academic Year).

Website: $\quad$ http://www.columbia.edu/dlc/wp/econ/index.html.

You may download any papers found on this site.

For Ordering Hardcopies:

Domestic orders for discussion papers are available for purchase at the cost of $\$ 8.00$ (U.S.) Per paper and $\$ 140.00$ (US) for the series.

Foreign orders cost $\$ 10.00$ (US) per paper and $\$ 185.00$ for the series.

To order discussion papers, please write to the Discussion Paper Coordinator at the above address along with a check for the appropriate amount, made payable to Department of Economics, Columbia University. Please be sure to include the series number of the requested paper when you place an order. 
1996-97 Discussion Papers

Economics Department, Columbia University

\begin{tabular}{|c|c|c|}
\hline Seridestro & 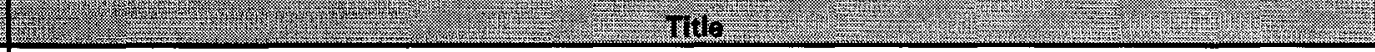 & Aluthors: \\
\hline $9697-01$ & Fertility Behavior Under Income Uncertainty & Ranjan, P. \\
\hline $9697-02$ & Trade Restrictions, imperfect Competition and National Welfare with Foreign Capital Inflows & Ranjan, $\mathbf{P .}$ \\
\hline $9697-03$ & Restructuring an Industry during Transition: a Two-Priced Model & Ericson, R. \\
\hline$\overline{9697-04}$ & A Conformity Test for Cointegration & Dhrymes, P. \\
\hline $9697-05$ & $\begin{array}{l}\text { Low-Wage Employment Subsidies in a Labor-Turnover Model of the 'Natural Rate' (November } \\
\text { 1996) }\end{array}$ & $\begin{array}{l}\text { Hoon, H.T. } \\
\text { Phelps, E. }\end{array}$ \\
\hline $9697-06$ & The Knowledge Revolution & Chichilnisky, G. \\
\hline $9697-07$ & The Role of Absolute Continuity in "Merging Opinions" and "Rational Learning" & $\begin{array}{l}\text { Miller. R. } \\
\text { Sanchirico, C.W. }\end{array}$ \\
\hline $9697-08$ & The Soviet Bloc and the Soviet Union: Why did they fall apart? & Desai, P. \\
\hline $9697-09$ & Regionalism and Multilateral Tariff Cooperation & $\begin{array}{l}\text { Bagwell, K. } \\
\text { Staiger, R. }\end{array}$ \\
\hline $9697-10$ & Supplier Relations and the Market Context: A theory of handshakes & McLaren, J. \\
\hline $9697-11$ & Vertical Foreclosure with the Choice of Input Specifications & $\begin{array}{l}\text { Choi, J.P. } \\
\text { Yi, S. }\end{array}$ \\
\hline $9697-12$ & Equilibrium Vertical Foreclosure with Investment & $\begin{array}{l}\text { Choi, J.P. } \\
\text { Yi, S. }\end{array}$ \\
\hline $9697-13$ & Going Global: Transition from Plan to Market in the World Economy & Desai, $\mathrm{P}$. \\
\hline $9697-14$ & Reciprocity, Non-discrimination and Preferential Agreements in the Multilateral Trading System & $\begin{array}{l}\text { Bagwell, K. } \\
\text { Staiger, R. }\end{array}$ \\
\hline $9697-15$ & Russia's Transition Toward the World Economy: Is the Market Mechanism Working? & Desai, $\mathbf{P}$. \\
\hline $9697-16$ & A Dynamic Analysis of Licensing: The "Boomerang" Effect and Grant-Back Clauses & Choi, J.P. \\
\hline
\end{tabular}

